University of Nebraska - Lincoln

DigitalCommons@University of Nebraska - Lincoln

Agronomy \& Horticulture -- Faculty Publications

Agronomy and Horticulture Department

4-1983

\title{
Variability for Traits Used to Estimate Silage Quality in Forage Sorghum Hybrids
}

Jeffrey F. Pedersen

University of Nebraska-Lincoln, jpedersen1@unl.edu

Francis A. Haskins

University of Nebraska-Lincoln, fhaskins@neb.rr.com

H. J. Gorz

R. Britton

Follow this and additional works at: https://digitalcommons.unl.edu/agronomyfacpub

Part of the Plant Sciences Commons

Pedersen, Jeffrey F.; Haskins, Francis A.; Gorz, H. J.; and Britton, R., "Variability for Traits Used to Estimate Silage Quality in Forage Sorghum Hybrids" (1983). Agronomy \& Horticulture -- Faculty Publications. 295. https://digitalcommons.unl.edu/agronomyfacpub/295

This Article is brought to you for free and open access by the Agronomy and Horticulture Department at DigitalCommons@University of Nebraska - Lincoln. It has been accepted for inclusion in Agronomy \& Horticulture -Faculty Publications by an authorized administrator of DigitalCommons@University of Nebraska - Lincoln. 


\title{
Variability for Traits Used to Estimate Silage Quality in Forage Sorghum Hybrids ${ }^{1}$
}

\author{
J. F. Pedersen, F. A. Haskins, H. J. Gorz, and R. Britton ${ }^{2}$
}

\begin{abstract}
The variation among $49 F_{1}$ forage sorghum [Sorghum bicolor $(L$. Moench.] hybrids from a $7 \times 7$ cross-classified design was explored in 1979 and 1980 for the following silage traits: dry matter (DM), crude protein, in vitro dry matter disappearance (IVDMD), neutral detergent fiber, acid detergent fiber, acid detergent lignin, ammonia, lactate, and Brix of the juice from fresh stalks. Wider ranges generally were found for male than for female parental means. Means for most traits were significantly different among entries. Significant differences among hybrid means over males and over females were found for only DM, IVDMD, and Brix. Interactions with years existed for most traits. Genetic ratios calculated from the mean squares indicated that general combining ability was important for DM, IVDMD, and Brix. Simple correlation coefficients between traits measured on silage and on fresh-dried samples from the same hybrids were all significant. In view of the effort required to make and evaluate silage samples, initial selection for traits used to estimate quality in fresh-dried samples appears to be the best approach for improving the quality of forage sorghum silage.
\end{abstract}

Additional index words: Sorghum bicolor (L.) Moench., Protein, IVDMD, Fiber, Lignin, Ammonia, Lactate, Brix, Combining ability.

$\mathrm{T}$ HE inheritance of several constituents used to estimate quality in dried samples from freshly harvested forage sorghum [Sorghum bicolor (L.) Moench.] hybrids was reported in an earlier paper (19). Forage sorghums often are preserved and utilized as silage (18), and some constituents used to estimate quality have been shown to be altered during the ensiling process (5). Information about the inheritance of silage constituents is needed in forage sorghum breeding programs.

The large number of silage samples required in inheritance and breeding studies necessitates the use of simple, economical, miniature silos. Sealed glass canning jars meet this requirement and have been used experimentally for more than 50 years $(1,6,11)$. It is recognized that the silage produced in miniature silos may differ from that produced in field scale silos, but small silos provide a feasible means of obtaining reasonable estimates of silage quality (16) from a large number of entries.
Some factors that can affect silage quality include dry matter percentage at time of ensiling, lactic acid concentration, ammonia content, and availability of fermentable carbohydrates. Many traits such as in vitro dry matter disappearance (IVDMD), crude protein (CP), dry matter (DM) percentage, neutral detergent fiber (NDF), acid detergent fiber (ADF), and acid detergent lignin (ADL), can be used to estimate quality in both freshly harvested sorghum forage and silage.

Ward et al. (24) found that lower DM percentage of sorghum silage resulted in lower DM intake. However, this relationship was probably secondary since Thomas et al. (22) demonstrated that a change in the DM content of a silage at the time of feeding did not alter the DM intake. The intake depression associated with higher moisture silages may be due to their increased levels of organic acids, particularly lactic acid (9). Thomas et al. (22) reported a reduction in dry matter intake of silage when lactic acid was added to the silage or introduced directly into the rumen. McLeod et al. (15) found that increases in $\mathrm{pH}$ of the silage increased DM intake while decreases in $\mathrm{pH}$ reduced DM intake.

The breakdown of proteins to ammonia is considered detrimental to silage quality (3) because palatability is reduced and some of the ammonia is lost through volatilization as the silage is fed. Some workers also have associated higher soluble $\mathrm{N}$ content with lowered intake of silage (17).

McCullough and Cummins (14) reported that sorghum silages are deficient in fermentable carbohydrates, the energy source required for the desired lactate-type ensiling process. Similarly, Zimmer (25) stated that low sugar con-

\footnotetext{
${ }^{1}$ Joint contribution of the USDA-ARS and the Nebraska Agric. Exp Stn., Lincoln. Published as Paper No. 6783, Journal Series, Nebraska Agric. Exp. Stn. Received 12 Feb. 1982. The work reported was conducted under Nebraska Exp. Stn. Projects 12-088 and 12-114.

${ }^{2}$ Formerly graduate research assistant (now assistant professor of agronomy, Auburn Univ., Auburn, AL 36849); George Holmes professor of agronomy; supervisory research geneticist, USDA-ARS; and associate professor of animal science, Univ. of Nebraska, Lincoln, NE 68583 respectively.
} 
centrations contributed to a less desirable heterofermentive ensiling process. However, Gourley and Lusk (8) proposed that if more soluble carbohydrates are available than the 6 to $8 \%$ required for fermentation, the excess may be metabolized to $\mathrm{CO}_{2}$ and water. They also stated that sweet sorghum silages generally are inferior to intermediate- and graintype silages in terms of feeding value.

The objectives of this study were to determine the extent of variation among 49 experimental forage sorghum hybrids for several constituents used to estimate silage quality and to estimate the proportion of the total variation that was caused by genetic variation. In addition, general combining ability (GCA) and specific combining ability (SCA) effects were estimated.

\section{MATERIALS AND METHODS}

The $49 \mathrm{~F}_{1}$ hybrids used, growing conditions, harvesting and sampling techniques, and statistical and genetic analyses were described in an earlier paper (19). Pertinent information relative to this study is repeated here. The 49 hybrids were produced by crossing each of seven male-sterile lines ('Redlan', 'N35', 'N38', 'N48', 'N4692', 'KS5', 'N5013'3) to each of seven pollinator lines ['Early Hegari-Sart' (EH-SART) ${ }^{3}$, 'Early Hegari-White Sourless' (EH-WS) ${ }^{3}$, 'Early Hegari-Rox' (EH-Rox) ${ }^{3}$, 'N6229', 'Rox', 'White Collier' (WC), and 'H60-29'3].

The 49 hybrids were grown in a randomized complete block design with three replications at the University of Nebraska Field Laboratory, Mead, in 1979 and 1980 using standard agricultural practices for that area. Plots were three $9.14-\mathrm{m}$ rows spaced 0.76 $m$ apart with plants hand-thinned to a spacing of approximately $15 \mathrm{~cm}$. A $4.75-\mathrm{m}$ section of the middle row of each plot was harvested after all entries had reached physiological maturity (2427 Sept. 1979 and 6-7 Oct. 1980). Random subsamples were passed through a small chopper, mixed thoroughly, and packed as tightly as possible into the miniature silos which consisted of 0.95-liter glass jars. The jars were immediately sealed with new canning lids. The lids and jar tops were dipped in melted paraffin at the end of each day to ensure an airtight seal. The miniature silos were then incubated at $28 \mathrm{C}$ to promote a lactate-type fermentation (13).

After 4 weeks the ensiling process was assumed to be complete, the jars were opened, and subsamples were withdrawn for drying. The jars were again closed, and jars and contents were held in a freezer until additional subsamples were withdrawn for the preparation of extracts. The subsamples withdrawn for drying were weighed, dried to a constant weight at $57 \mathrm{C}$ in a forced-air oven, and reweighed. Data were collected for the following constituents used to estimate quality:

Percent DM. Calculated from the difference in weights of wet and dried silage samples.

Percent $C P$ (Percent $N \times 6.25)$. Determined by the Kjeldahl procedure (10).

IVDMD. Determined by the two-stage technique of Tilley and Terry (23) and expressed as a percentage.

Percent NDF. Determined by the high concentrate procedure of Robertson and Van Soest (20).

Percent $A D F, A D L$. Determined by the detergent fractionation procedures of Goering and Van Soest (7).

Extracts were prepared from separate subsamples of the wet silage using a modification of Byer's (4) extraction procedure for organic acid analysis in fermented feeds. Twenty-five grams of silage, $70 \mathrm{ml}$ of $0.01 \mathrm{~N} \mathrm{H}_{2} \mathrm{SO}_{4}$, and a thymol crystal to prevent bacterial growth, were placed in a $125-\mathrm{ml}$ Erlenmeyer flask, mixed, and refrigerated for 24 hours to equilibrate. The liquid was filtered

\footnotetext{
${ }^{3}$ Experimental forage sorghum lines.
}

through Whatman \#40 filter paper, and the filtrate was frozen and thawed once to aid in precipitation. Four milliliters of the thawed suspension was placed in a centrifuge tube with $1 \mathrm{ml}$ of $10 \%(\mathrm{w} / \mathrm{v})$ trichloroacetic acid and centrifuged for $15 \mathrm{~min}$ at 12,000 $\times g$. The supernatant was decanted and frozen for later analyses of lactate and ammonia. The determination of lactic acid content involved the use of Barker and Summerson's (2) coiorimetric technique, and ammonia content was determined by an adaptation of the indophenol method of McCullough (12).

Measurements of Brix from three stalks/plot were made using a hand-held refractometer on 17 and 18 Sept. 1979 and on 9 Oct. 1980. Juice from the fifth internode, counting the peduncle as the first, was squeezed onto the refractometer stage for these readings.

The genetic analyses of these data followed the method described by Ross et al. (21). Although described in an earlier paper (19), the procedure is repeated here for convenience. The entry source of variation was partitioned into females, males, and females $X$ males, and the entry $X$ year interactions were partitioned into females $X$ years, males $X$ years, and females $X$ males $X$ years. Mean squares (MS) were equated to their expected values and solved for components estimating the variance among the fixed effects in the corresponding sources of variation. F-tests were made for females as $\mathrm{MS}_{\mathrm{f}} / \mathrm{MS}_{\mathrm{fy}}$, for males as $\mathrm{MS}_{\mathrm{m}} / \mathrm{MS}_{\mathrm{my}}$, for females $X$ males as $\mathrm{MS}_{\mathrm{fm}} / \mathrm{MS}_{\mathrm{fmy}}$, and for females $X$ males $X$ years as $\mathrm{MS}_{\mathrm{fmy}} / \mathrm{MS}_{\mathrm{e}}$

Genetic ratios were estimated as follows:

$$
\begin{gathered}
\frac{\theta_{\mathrm{f}}^{2}}{\left(\sigma_{\mathrm{e}}^{2} / \mathrm{RMY}+\sigma_{\mathrm{fm} y}^{2} / \mathrm{MY}+\theta_{\mathrm{fm}}^{2} / \mathrm{M}+\sigma_{\mathrm{fy}}^{2} / \mathrm{Y}+\theta_{\mathrm{f}}^{2}\right)}=\frac{\theta_{\mathrm{f}}^{2}}{\theta_{\mathrm{P}_{\mathrm{f}}}^{2}}, \\
\frac{\theta_{\mathrm{m}}^{2}}{\left(\sigma_{\mathrm{e}}^{2} / \mathrm{RFY}+\sigma_{\mathrm{fmy}}^{2} / \mathrm{FY}+\theta_{\mathrm{fm}}^{2} / \mathrm{F}+\sigma_{\mathrm{my}}^{2} / \mathrm{Y}+\theta_{\mathrm{m}}^{2}\right)}=\frac{\theta_{\mathrm{m}}^{2}}{\theta_{\mathrm{P}_{\mathrm{m}}}^{2}}, \text { and } \\
\frac{\theta_{\mathrm{fm}}^{2}}{\left(\sigma_{\mathrm{e}}^{2} / \mathrm{RY}+\sigma_{\mathrm{fm} y}^{2} / \mathrm{Y}+\theta_{\mathrm{fm}}^{2}\right)}=\frac{\theta_{\mathrm{fm}}^{2}}{\theta_{\mathrm{Pfm}}^{2}},
\end{gathered}
$$

where the symbol $\theta^{2}$ refers to fixed effects and $\sigma^{2}$ refers to random effects.

The ratio $\theta_{\mathrm{f}}^{2} / \theta_{\mathbf{P}_{\mathrm{f}}}^{2}$ estimates GCA based on females, $\theta_{\mathbf{m}}^{2} / \theta_{\mathbf{P}_{\mathrm{m}}}^{2}$ estimates GCA based on males, and $\theta_{\mathrm{fm}}^{2} / \theta_{\mathrm{Pfm}}^{2}$ estimates SCA based on females $\times$ males. The symbols $\theta_{\mathrm{f}}^{2}, \theta_{\mathrm{m}}^{2}, \sigma_{\mathrm{fy}}^{2}, \sigma_{\mathrm{my}}^{2}, \theta_{\mathrm{fm}}^{2}, \sigma_{\mathrm{fmy}}^{2}$, and $\sigma_{\mathrm{e}}^{2}$ are the components for females, males, females $X$ years, males $X$ years, females $X$ males, females $X$ males $X$ years, and error, respectively; the symbol $\theta_{\mathrm{P}}^{2}$ with the appropriate subscript is analogous to an estimate of phenotypic variance. The symbols $\mathbf{F}, \mathbf{M}$, $\mathrm{Y}$, and $\mathrm{R}$ in the denominator indicate the number of observations on females, males, years, and replications, respectively.

As pointed out by Ross et al. (21), statistical treatment of fixed lines to draw inferences about hypothetical populations, is not entirely appropriate. However, with qualifications, quantitative genetic information can be drawn from such studies that may aid in the improvement of quality and yield of forage sorghum.

\section{RESULTS AND DISCUSSION}

Significant differences were found among entries for all traits except percent CP and lactic acid content. Comparisons of parental means showed that low IVDMD values were generally associated with low Brix readings (Table 1). The range of mean values for most traits was greater for male parents than for female parents. High IVDMD and Brix readings and low ammonia levels usually occurred in hybrids involving White Collier as the male parent.

Mean squares for all measured traits are shown in Table 2. Significant differences among hybrid means over males $(\mathrm{M})$ and over females (F) were found for only DM, IVDMD, and Brix. Significant differences among hybrid means averaged over males were also found for ADL. A 
Table 1. Means of silage quality traits of $49 \mathrm{~F}_{1}$ forage sorghum hybrids grown at Mead, Nebr. in 1979 and 1980.

\begin{tabular}{|c|c|c|c|c|c|c|c|c|c|}
\hline \multirow[b]{2}{*}{ Group } & \multicolumn{9}{|c|}{ Trait } \\
\hline & $\mathbf{D M}$ & $\mathrm{CP}$ & IVDMD & NDF & ADF & ADL & Brix & Ammonia & Lactate \\
\hline & & & $-5=$ & $-\%$ & & & & $-\mathbf{g} / \mathbf{k}$ & $\mathbf{M}$ \\
\hline \multicolumn{10}{|l|}{ Male mean } \\
\hline $\begin{array}{l}\text { EH-Sart } \dagger \\
\text { EH-WS } \\
\text { EH-Rox } \\
\text { N6229 } \\
\text { H60-29 } \\
\text { Rox } \\
\text { WC } \\
\text { LSD (0.05) }\end{array}$ & $\begin{array}{r}27.4 \\
31.8 \\
32.8 \\
28.0 \\
31.6 \\
28.6 \\
31.6 \\
1.3\end{array}$ & $\begin{array}{c}5.7 \\
6.4 \\
6.2 \\
5.9 \\
6.8 \\
6.4 \\
6.0 \\
\text { NS }\end{array}$ & \begin{tabular}{r|}
50.2 \\
53.2 \\
53.6 \\
51.2 \\
53.3 \\
54.1 \\
56.7 \\
3.2
\end{tabular} & $\begin{array}{l}\mathbf{5 7 . 1} \\
\mathbf{5 3 . 8} \\
\mathbf{5 4 . 6} \\
\mathbf{5 7 . 0} \\
\mathbf{5 4 . 4} \\
\mathbf{5 4 . 3} \\
\mathbf{5 1 . 3} \\
\text { NS }\end{array}$ & $\begin{array}{l}33.9 \\
30.6 \\
30.9 \\
33.6 \\
30.7 \\
31.4 \\
28.7 \\
\text { NS }\end{array}$ & $\begin{array}{l}6.0 \\
6.3 \\
6.2 \\
6.2 \\
5.9 \\
6.4 \\
5.2 \\
0.5\end{array}$ & $\begin{array}{r}10.4 \\
9.1 \\
10.6 \\
9.1 \\
10.6 \\
10.5 \\
13.7 \\
2.2\end{array}$ & $\begin{array}{l}0.34 \\
0.29 \\
0.25 \\
0.31 \\
0.37 \\
0.27 \\
0.24 \\
\text { NS }\end{array}$ & $\begin{array}{l}44.1 \\
33.3 \\
33.0 \\
40.2 \\
36.3 \\
40.2 \\
36.3 \\
\text { NS }\end{array}$ \\
\hline \multicolumn{10}{|c|}{ Fernale mean } \\
\hline $\begin{array}{l}\text { N5013 } \\
\text { N48 } \\
\text { N4692 } \\
\text { KS5 } \\
\text { N38 } \\
\text { N35 } \\
\text { Redlan } \\
\text { LSD (0.05) }\end{array}$ & $\begin{array}{r}29.3 \\
29.7 \\
28.9 \\
30.7 \\
30.7 \\
31.2 \\
31.3 \\
1.4\end{array}$ & $\begin{array}{l}6.1 \\
6.1 \\
6.1 \\
6.2 \\
6.4 \\
6.3 \\
6.1 \\
\text { NS }\end{array}$ & \begin{tabular}{r|}
52.5 \\
53.8 \\
53.6 \\
54.9 \\
53.2 \\
53.2 \\
51.0 \\
1.6
\end{tabular} & $\begin{array}{l}56.0 \\
54.1 \\
54.7 \\
52.4 \\
54.6 \\
53.3 \\
57.5 \\
\text { NS }\end{array}$ & $\begin{array}{l}33.0 \\
31.0 \\
32.0 \\
30.2 \\
30.9 \\
30.1 \\
32.6 \\
\text { NS }\end{array}$ & $\begin{array}{l}6.4 \\
5.6 \\
6.0 \\
5.7 \\
6.1 \\
6.0 \\
6.4 \\
\text { NS }\end{array}$ & $\begin{array}{r}11.7 \\
11.9 \\
11.0 \\
10.8 \\
11.0 \\
9.3 \\
8.3 \\
1.5\end{array}$ & $\begin{array}{l}0.29 \\
0.28 \\
0.28 \\
0.30 \\
0.30 \\
0.28 \\
0.33 \\
\text { NS }\end{array}$ & \begin{tabular}{l|}
39.8 \\
36.6 \\
39.9 \\
36.9 \\
37.7 \\
36.5 \\
36.4 \\
NS
\end{tabular} \\
\hline \multicolumn{10}{|c|}{ Overall mean and range } \\
\hline $\begin{array}{l}\text { Mean } \\
\text { Maximum } \\
\text { Minimum }\end{array}$ & $\begin{array}{l}30.3 \\
34.3 \\
26.1\end{array}$ & $\begin{array}{l}6.2 \\
7.3 \\
5.2\end{array}$ & $\begin{array}{l}53.2 \\
60.2 \\
48.3\end{array}$ & $\begin{array}{l}54.7 \\
59.6 \\
49.4\end{array}$ & $\begin{array}{l}31.4 \\
36.7 \\
27.1\end{array}$ & $\begin{array}{l}6.0 \\
7.3 \\
4.5\end{array}$ & $\begin{array}{r}10.6 \\
14.7 \\
6.2\end{array}$ & $\begin{array}{l}0.29 \\
0.45 \\
0.16\end{array}$ & $\begin{array}{l}37.7 \\
49.1 \\
26.8\end{array}$ \\
\hline
\end{tabular}

† Abbreviations for cultivars are as follows: Early Hegari-Sart (EH-Sart), Early Hegari-White Sourless (EH-WS), Early Hegari-Rox (EH-Rox) and White Collier (WC).

$\ddagger$ NS = not significant.

Table 2. Mean squares of silage quality traits of $49 F_{1}$ forage sorghum hybrids grown at Mead, Nebr. in 1979 and 1980.

\begin{tabular}{|c|c|c|c|c|c|c|c|c|c|}
\hline \multirow[b]{2}{*}{ Source } & \multicolumn{9}{|c|}{ Trait } \\
\hline & DM & $\mathrm{CP}$ & IVDMD & NDF & $\mathrm{ADF}$ & ADL & Brix & Ammonia & Lactate \\
\hline Year (Y) & 350.5 & 91.20 & 2160.3 & 573.4 & 23.5 & 42.2 & 76.8 & 0.038 & 80292 \\
\hline Female (F) & $37.1^{*}$ & 0.82 & $61.3^{*}$ & 121.5 & 55.6 & 3.8 & $72.9^{*}$ & 0.013 & 100 \\
\hline Male (M) & $200.5^{*}$ & 5.35 & $182.0^{*}$ & 167.7 & 135.4 & $7.2^{*}$ & $99.5^{*}$ & 0.096 & 685 \\
\hline $\mathbf{F} \times \mathbf{M}$ & 7.1 & 0.62 & 16.2 & 14.9 & 8.4 & 1.3 & 8.9 & $0.016^{*}$ & 118 \\
\hline $\mathbf{F} \times \mathbf{Y}$ & 6.5 & 0.75 & 8.7 & $31.6^{*}$ & $27.4^{*}$ & 2.0 & 8.3 & 0.011 & 169 \\
\hline $\mathbf{M} \times \mathbf{Y}$ & 5.8 & $4.24^{*}$ & $35.4^{*}$ & $40.6^{*}$ & $41.6^{*}$ & 0.9 & $17.2^{*}$ & $0.040^{*}$ & $233^{*}$ \\
\hline $\mathbf{F} \times \mathbf{M} \times \mathbf{Y}$ & 5.7 & 0.69 & 14.0 & 11.6 & 8.1 & 1.1 & 6.2 & 0.008 & 96 \\
\hline Error & 5.0 & 0.49 & 14.2 & 9.6 & 6.4 & 1.0 & 5.1 & 0.009 & 86 \\
\hline
\end{tabular}

* Significant at $P \leq 0.05$.

Table 3. Quantitative genetic estimates of silage quality traits in $49 F_{1}$ forage sorghum hybrids grown at Mead, Nebr. in 1979 and 1980.

\begin{tabular}{|c|c|c|c|c|c|c|}
\hline \multirow[b]{3}{*}{ Trait } & \multicolumn{6}{|c|}{ Parameter estimated $\dagger$} \\
\hline & \multicolumn{3}{|c|}{ Genotypic component } & \multicolumn{3}{|c|}{ Genetic ratio } \\
\hline & $\theta_{\mathrm{f}}^{2}$ & $\theta_{\mathrm{m}}^{2}$ & $\theta_{\mathrm{fm}}^{2}$ & $\theta_{\mathbf{f}}^{2} / \theta_{\mathbf{P}_{\mathrm{f}}}^{2}$ & $\theta_{\mathrm{m}}^{2} / \theta_{\mathrm{P}_{\mathrm{m}}^{\mathrm{z}}}$ & $\theta_{\mathrm{fm}}^{2} / \theta_{\mathrm{P}_{\mathrm{fm}}}^{2}$ \\
\hline DM & 0.70 & 4.60 & 0.22 & 0.79 & 0.96 & 0.19 \\
\hline CP & $0.32 \ddagger$ & $2.78 \ddagger$ & 0.00 & 0.17 & 0.22 & 0.00 \\
\hline IVDMD & 1.20 & 3.44 & 0.38 & 0.82 & 0.79 & 0.14 \\
\hline NDF & 2.06 & 2.95 & 0.55 & 0.71 & 0.74 & 0.22 \\
\hline $\mathrm{ADF}$ & 0.66 & 2.23 & 0.05 & 0.50 & 0.69 & 0.04 \\
\hline $\mathrm{ADL}$ & 0.04 & 0.15 & 0.04 & 0.43 & 0.85 & 0.17 \\
\hline Brix & 1.47 & 1.89 & 0.46 & 0.85 & 0.80 & 0.31 \\
\hline Ammonia & 0.00 & $0.11 \ddagger$ & $0.15 \ddagger$ & 0.00 & 0.50 & 0.53 \\
\hline Lactate & 0.00 & 10.25 & 3.60 & 0.00 & 0.63 & 0.18 \\
\hline
\end{tabular}

$\dagger \theta_{\mathrm{f}}^{z}, \theta_{\mathrm{m}}^{z}$, and $\theta_{\mathrm{fm}}^{z}$ are the variances for females, males, and females $\times$ males, respectively. $\theta_{\mathrm{P}}^{2}$ is the phenotypic variance for females, males, or females $\times$ males, as appropriate.

$\ddagger$ Actual value is quantity shown $\times 10^{-2}$.

significant $\mathrm{F} \times \mathrm{M}$ interaction occurred only for ammonia. The $F \times Y$ interaction was significant for NDF and ADF, and $M \times Y$ interactions were significant for all traits except $\mathrm{DM}$ and ADL. Even though a valid test of significance for the year mean squares cannot be made, the significant year interactions plus the large year mean square values indicate
Table 4. Correlation coefficients among several silage quality traits based on entry means from $49 \mathrm{~F}_{1}$ forage sorghum hy. brids grown at Mead, Nebr. in 1979 and 1980.

\begin{tabular}{lcccccc}
\hline & \multicolumn{6}{c}{ Trait } \\
\cline { 2 - 7 } Trait & IVDMD & NDF & ADF & ADL & Brix & Ammonia \\
\hline DM & $0.37^{*}$ & $-0.41^{*}$ & $-0.65^{*}$ & -0.16 & 0.00 & 0.26 \\
IVDMD & & $-0.83^{*}$ & $-0.80^{*}$ & $-0.49^{*}$ & $0.57^{*}$ & $-0.34^{*}$ \\
NDF & & & $0.91^{*}$ & $0.64^{*}$ & $-0.42^{*}$ & $0.35^{*}$ \\
ADF & & & & $0.62^{*}$ & $-0.31^{*}$ & $0.33^{*}$ \\
ADL & & & & & -0.40 & 0.09 \\
Brix & & & & & & $-0.34^{*}$ \\
\hline
\end{tabular}

* Significant at $P \leq 0.05$.

that the year effect was an important source of the variation in these studies.

Variance components and genetic ratios from the analyses of the traits are presented in Table 3 . Values for $\theta_{\mathrm{m}}^{2}$ were higher than those for $\theta_{\mathrm{f}}^{2}$ or $\theta_{\mathrm{fm}}^{2}$ for most traits. High $\theta_{\mathrm{f}}^{2} /$ $\theta_{\mathrm{Pr}}^{2}$ and $\theta_{\mathrm{m}}^{2} / \theta_{\mathrm{P}_{\mathrm{m}}}^{2}$ values for DM, IVDMD, and Brix indicate that GCA effects were more important for these traits than SCA effects. The high $\theta_{\mathrm{m}}^{2} / \theta_{\mathrm{Pm}_{\mathrm{m}}}^{2}$ value for lactate implies the same for the male group of parents only. Ratios with extremely low values probably reflect a lack of repeatability in measuring the corresponding traits or a lack of variability in the parental populations, or both.

Simple correlation coefficients for pairs of constituents 
used to estimate quality in this study are shown in Table 4. As was expected, IVDMD had a strong negative association with both NDF and ADF, while NDF and ADF exhibited a strong positive relationship.

The simple correlation coefficients for the relationships of values of constituents used to estimate quality for freshdried samples (19) to those values for ensiled samples based on entry means $(\mathrm{N}=49$ ) were 0.84 for $\mathrm{DM}, 0.81$ for $\mathrm{CP}$, 0.65 for IVDMD, 0.61 for NDF, 0.68 for ADF, and 0.54 for ADL. All were significant at least at the 0.05 level of probability.

Most forage breeding programs utilize fresh-dried samples for quality determinations. This may be most efficient, in view of the time and expense involved in actual silage evaluation and the relatively high correlation coefficients shown above for traits measured on fresh-dried vs. ensiled samples. By initially screening fresh-dried samples for traits shown to have high GCA such as IVDMD, NDF, and Brix most efficient progress should be made. Then a more detailed study of silage quality factors could be made on a smaller number of genotypes.

\section{REFERENCES}

1. Autrey, K.M., C.B. Knodt, and P.S. Williams. 1947. Grass and legume silage studies using 2-quart glass jars as miniature silos. J. Dairy Sci. 30:775-785.

2. Barker, S.B., and W.H. Summerson. 1941. The colorimetric determination of lactic acid in biological material. J. Biol. Chem. 138:535554.

3. Bergen, W.G. 1975. The influence of silage fermentation on nitrogen utilization. p. 171-181. In 2nd Int. Silage Res. Conf. Chicago, Ill., 30 Nov.-2 Dec. 1975. National Silo Assoc. Inc., Cedar Falls, Iowa.

4. Byers, F.M. 1980. Effects of limestone, monensin, and feeding level on corn silage net energy value and composition of growth in cattle. J. Anim. Sci. 50:1127-1135.

5. Danley, M.M., and R.L. Vetter. 1973. Changes in carbohydrate and nitrogen fractions and digestibility of forages: Maturity and ensiling. J. Anim. Sci. 37:994-999.

6. Garber, R.J., and T.E. Odland. 1927. Mason jars as miniature silos. J. Am. Soc. Agron. 19:259-263.

7. Goering, H.K., and P.J. Van Soest. 1970. Forage fiber analyses. USDA Agric. Handb. No. 379.

8. Gourley, L.M., and J.W. Lusk. 1977. Sorghum silage quality as affected by soluble carbohydrate, tannins, and other factors. Proc. Annu. Corn and Sorghum Res. Conf. 32:157-170.

9. Harris, C., E.W.F. Raymond, and R.F. Wilson. 1966. The voluntary intake of silage. p. 564-568. In A.G. Hill (ed.). Proc. 10th Int. Grassland Congr., Helsinki, Finland. Finnish Grassl. Assoc., Helsinki, Finland.

10. Horwitz, W. 1960. Association of Official Agricultural Chemists. Official methods of analyses of the A.O.A.C. (9th ed.), A.O.A.C., Washington, D.C

11. Klosterman, E.W., R.R. Johnson, A.L. Moxon, and H.W. Scott. 1963 Feeding value of limestone treated corn silages for fattening cattle. Ohio Agric. Exp. Stn. Bull. 934.

12. McCullough, H. 1967. The determination of ammonia in whole blood by a direct colorimetric method. Clin. Chim. Acta 17:297-304.

13. McCullough, M.E. 1961. A study of factors associated with silage fermentation and dry matter intake by dairy cows. J. Anim. Sci. 20:288291.

14. --, and D.G. Cummins. 1974. Factors involved in sorghum silage quality. Georgia Agric. Res. 15:8-10.

15. McLeod, D.S., R.J. Wilkins, and W.F. Raymond. 1970. The voluntary intake by sheep and cattle of silages differing in free-acid content. J. Agric. Sci. 75:311-319.

16. Meiske, J.C., J.G. Linn, and R.D. Goodrich. 1975. Types of laboratory silos and an evaluation of their usefulness. p. 99-126. In 2nd Int. Silage Res. Conf. Chicago, Ill, 30 Nov.-2 Dec. 1975. National Silo Assoc. Inc., Cedar Falls, Iowa.

17. Neumark, H., A. Bondi, and R. Volcani. 1964. Amines, aldehydes, and ketones in silage and their effect on food intake by ruminants. $\mathrm{J}$. Sci. Food Agric. 15:487-492.

18. Owen, F.G., and W.J. Moline. 1970. Sorghum for forage. p. 382 415. In J.S. Wall and W.M. Ross (ed.) Sorghum production and utilization. AVI Pub. Co., Inc., Westport, Conn.

19. Pedersen, J.F., H.J. Gorz, F.A. Haskins, and W.M. Ross. 1982. Variability for quality and agronomic traits in forage sorghum hybrids. Crop Sci. 22:853-856.

20. Robertson, J.B., and P.J. Van Soest. 1977. Dietary fiber estimation in concentrate feedstuffs. J. Anim. Sci. 45 (Supplement 1):254.

21. Ross, W.M., H.J. Gorz, F.A. Haskins, and K.D. Kofoid. 1979. Combining ability in forage sorghum hybrids. Maydica 24:83-93.

22. Thomas, J.W., L.A. Moore, M. Okamoto, and J.F. Sykes. 1961. A study of factors affecting rate of intake of heifers fed silage. J. Dairy Sci. 44:1471-1483.

23. Tilley, J.M.A., and R.A. Terry. 1963. A two-stage technique for the in vitro digestion of forage crops. J. Br. Grassl. Soc. 18:104-111.

24. Ward, G.M., F.W. Boren, E.F. Smith, and J.R. Brethour. 1966. Relation between dry matter content and dry matter consumption of sorghum silage. J. Dairy Sci. 49:339-402.

25. Zimmer, E. 1971. Factors affecting silage fermentation in silo. p. 58 78. In Int. Silage Res. Conf., Tech. Papers. 